Proceedings

\title{
Autothermal Thermophilic Aerobic Digestion of Municipal Sewage Sludge in Poland. Review ${ }^{+}$
}

\author{
Izabela Bartkowska *, Paweł Biedka and Izabela Anna Talalaj \\ Department of Water Supply and Sewerage, Bialystok University of Technology, Wiejska 45A Street, \\ 15-351 Bialystok, Poland; p.biedka@pb.edu.pl (P.B.); i.talalaj@pb.edu.pl (I.A.T.) \\ * Correspondence: i.bartkowska@pb.edu.pl; Tel.: +48-085-746-9649 \\ + Presented at the 9th Innovations-Sustainability-Modernity-Openness Conference (ISMO'20), \\ Bialystok, Poland, 20-21 May 2020.
}

Published: 15 July 2020

\begin{abstract}
This paper presents the process of autothermal thermophilic aerobic digestion (ATAD). The installations used in municipal sewage treatment plants in Poland were reviewed. The adopted solutions for sludge management and parameters of operating installations were presented. Attention was also drawn to the energy consumption of the process. On the basis of research carried out in the years 2003-2019 in the plants in question, the characteristics of sludge after the ATAD process were presented. The parameters that determine the usefulness of the sludge as an organic fertilizer are indicated above all.
\end{abstract}

Keywords: ATAD; autothermal thermophilic aerobic digestion; natural utilisation of sewage sludge; organic fertilizers; sewage sludge

\section{Introduction}

Municipal sewage sludge treatment plants are an essential element of surface water protection systems. However, they cause a real nuisance to the surrounding environment in terms of air quality, acoustic climate or soil surface protection. One of the problems is the generation of a significant amount of different types of waste. These include municipal sewage sludge. The increasing amount of such sludge forces the search for methods of its final utilization.

There are many ways to process sewage sludge. One of them is the process of autothermal thermophilic aerobic digestion (ATAD), which is the subject of this paper. This process ensures full stabilization, hygienization and even disinfection of sludge, making it a biomass that can be used for natural purposes.

The cognitive aim of this study was to systematize the knowledge on the process of autothermal thermophilic stabilization of sewage sludge, which is the result of experience resulting from participation in the design, installation, technological start-up and operation of existing facilities. The presented material has been developed on the basis of many years of research carried out in eleven municipal sewage treatment plants, where sewage sludge is processed in the process of autothermal thermophilic aerobic digestion.

\section{The Process and Its Technology Solution}

The thermophilic stabilisation technology, which is used in treatment plants in Poland, was developed by Hubert K. E. Fuchs. In the 1970s, the first installation was built in Germany in Vilsbiburg, which is still operating today. Outside Western Europe, such plants operate in the USA, Canada, and Japan [1]. 
An essential role in the process of thermophilic stabilisation is played by microorganisms, thanks to which the decomposition of organic compounds contained in sewage sludge is possible [2]. It basically takes place in two stages. Hydrolysis of complex organic compounds (proteins, carbohydrates, and fats) as well as cell hydrolysis of dying microorganisms occurs in the first stage. These phenomena are caused by extracellular enzymes produced by thermophilic bacteria. In the second stage, thermophilic microorganisms oxidise the water-soluble hydrolysis products to low-energy compounds. These reactions are accompanied by heat release, and the final substances of these changes are $\mathrm{CO}_{2}, \mathrm{H}_{2} \mathrm{O}$ and $\mathrm{NH}_{3}[3-5]$.

Based on the hypothetical organic matter of the $\mathrm{C}_{5} \mathrm{H}_{7} \mathrm{NO}_{2}$ cell representing activated sludge $[5,6]$, the process can be presented as the following stoichiometric reactions:

$$
\begin{gathered}
\mathrm{C}_{5} \mathrm{H}_{7} \mathrm{NO}_{2}+5 \mathrm{O}_{2} \rightarrow 5 \mathrm{CO}_{2}+2 \mathrm{H}_{2} \mathrm{O}+\mathrm{NH}_{3}+\text { energy } \\
\mathrm{C}_{5} \mathrm{H}_{7} \mathrm{NO}_{2}+7 \mathrm{O}_{2} \rightarrow 5 \mathrm{CO}_{2}+3 \mathrm{H}_{2} \mathrm{O}+\mathrm{NO}_{3}^{-}+\mathrm{H}^{+}+\text {energy }
\end{gathered}
$$

In the first reaction the nitrogen bound in organic compounds is ammonified and ammonia is formed. The second reaction shows the nitrification process. The stoichiometric relationships show that theoretically $1.42 \mathrm{~kg}$ of oxygen per $\mathrm{kg}$ of active cell mass is needed for the first reaction and 1.98 $\mathrm{kg}$ of oxygen per $\mathrm{kg}$ of cells for the second reaction. In reality, however, it is different, as many factors influence the oxygen demand for the process. Nitrification during auto-thermal stabilization is practically nonexistent. Despite air supply, nitrification above $30^{\circ} \mathrm{C}$ is inefficient [5].

The process takes place in two- or three-stage reactors. The number of reactors is usually 2 . In one of the treatment plants, the installation consists of 6 reactors that operate in three two-stage process lines. In 6 treatment plants, there are installations consisting of two reactors operating in a two-stage system. In the remaining 4 treatment plants, there is an installation consisting of three reactors, which can operate in two or three stages. Selected technical and technological parameters of the reactors are shown in Tables 1 and 2.

\begin{tabular}{|c|c|c|c|c|c|c|}
\hline \multirow[b]{2}{*}{$\begin{array}{c}\text { Subsequent } \\
\text { Treatment } \\
\text { Plants (WWTP) }\end{array}$} & \multirow{2}{*}{$\begin{array}{c}\text { Average } \\
\text { Daily Plant } \\
\text { Capacity } \\
\left(\mathrm{m}^{3} / \mathrm{d}\right)\end{array}$} & \multicolumn{3}{|c|}{ Reactor Dimensions (m) } & \multirow{2}{*}{$\begin{array}{c}\text { Reactor } \\
\text { Useful } \\
\text { Capacity } \\
\left(\mathrm{m}^{3}\right)\end{array}$} & \multirow{2}{*}{$\begin{array}{l}\text { Total Dwell Time } \\
\text { of the Sludge } \\
\text { in the Installation } \\
\text { (d) }\end{array}$} \\
\hline & & $\begin{array}{l}\text { Internal } \\
\text { Diameter }\end{array}$ & $\begin{array}{c}\text { Total } \\
\text { Height }\end{array}$ & $\begin{array}{c}\text { Filling } \\
\text { Height with } \\
\text { Sludge }\end{array}$ & & \\
\hline WWTP_a & 90 & 8.40 & 4.00 & 3.35 & 185 & 8.2 \\
\hline WWTP_b & 34 & 7.71 & 3.60 & 2.80 & 130 & 7.65 \\
\hline WWTP_c & 40 & 8.50 & 3.50 & 2.70 & 153 & 7.66 \\
\hline WWTP_d & 27 & 8.00 & 3.30 & 2.50 & 125 & 9.3 \\
\hline WWTP_e & 30 & $\begin{array}{l}9.20 \\
6.50 *\end{array}$ & $\begin{array}{c}3.52 \\
3.52 *\end{array}$ & $\begin{array}{l}2.70 \\
270^{*}\end{array}$ & 180 & 9.3 \\
\hline WWTP_f & 46 & $\begin{array}{l}0.40 \\
9.42\end{array}$ & $\begin{array}{c}3.32 \\
3.80\end{array}$ & 3.00 & 209 & 9.1 \\
\hline WWTP_g & 16.7 & 6.00 & 3.40 & 2.60 & 73.5 & 8.8 \\
\hline
\end{tabular}

Table 1. Technical and technological parameters of two-stage reactors.

* Second stage reactor dimensions.

In the plants listed in Table 1, the reactors operate in series as a two-stage system.

\begin{tabular}{|c|c|c|c|c|c|c|}
\hline \multirow{2}{*}{$\begin{array}{c}\text { Subsequent } \\
\text { Sludge } \\
\text { Treatment } \\
\text { Plants (WWTP) }\end{array}$} & \multirow{2}{*}{$\begin{array}{c}\text { Average } \\
\text { Daily Plant } \\
\text { Capacity } \\
\left(\mathrm{m}^{3} / \mathrm{d}\right)\end{array}$} & \multicolumn{3}{|c|}{ Reactor Sizes (m) } & \multirow{2}{*}{$\begin{array}{c}\text { Useful } \\
\text { Reactor } \\
\text { Capacity } \\
\left(\mathbf{m}^{3}\right)\end{array}$} & \multirow{2}{*}{$\begin{array}{l}\text { Total Dwell Time } \\
\text { of the Sludge } \\
\text { in the Installation } \\
\text { (d) }\end{array}$} \\
\hline & & $\begin{array}{c}\text { Internal } \\
\text { Diameter }\end{array}$ & $\begin{array}{c}\text { Total } \\
\text { Height }\end{array}$ & $\begin{array}{l}\text { Sludge } \\
\text { Filling } \\
\text { Height }\end{array}$ & & \\
\hline WWTP_h & 58 & 8.57 & 3.80 & 3.00 & 173 & 8.95 \\
\hline WWTP_i & 96.6 & 9.43 & 4.36 & 3.50 & 244 & 7.6 \\
\hline WWTP_j & 45.5 & 8.35 & 3.50 & 2.50 & 137 & 9.0 \\
\hline WWTP_k & 70 & 8.50 & 3.80 & 3.00 & 170 & 7.3 \\
\hline
\end{tabular}

Table 2. Technical and technological parameters of three-reactor installations. 
The plants listed in Table 2 are ATAD plants consisting of three reactors arranged in an isosceles triangle. The armament of these tanks allows for one-, two- and three-stage operation.

\section{Process Energy Consumption}

Due to the high rate of oxygen absorption by thermophilic organisms, there are high energy requirements for reactor aeration. The obvious disadvantage of the process of autothermal thermophilic stabilization is the cost of aeration, which, however, can be significantly reduced if the equipment is properly designed and the system is correctly operated. The percentage share of individual technological processes in the total annual electricity consumption in one of the sewage treatment plants is shown in Figure 1.

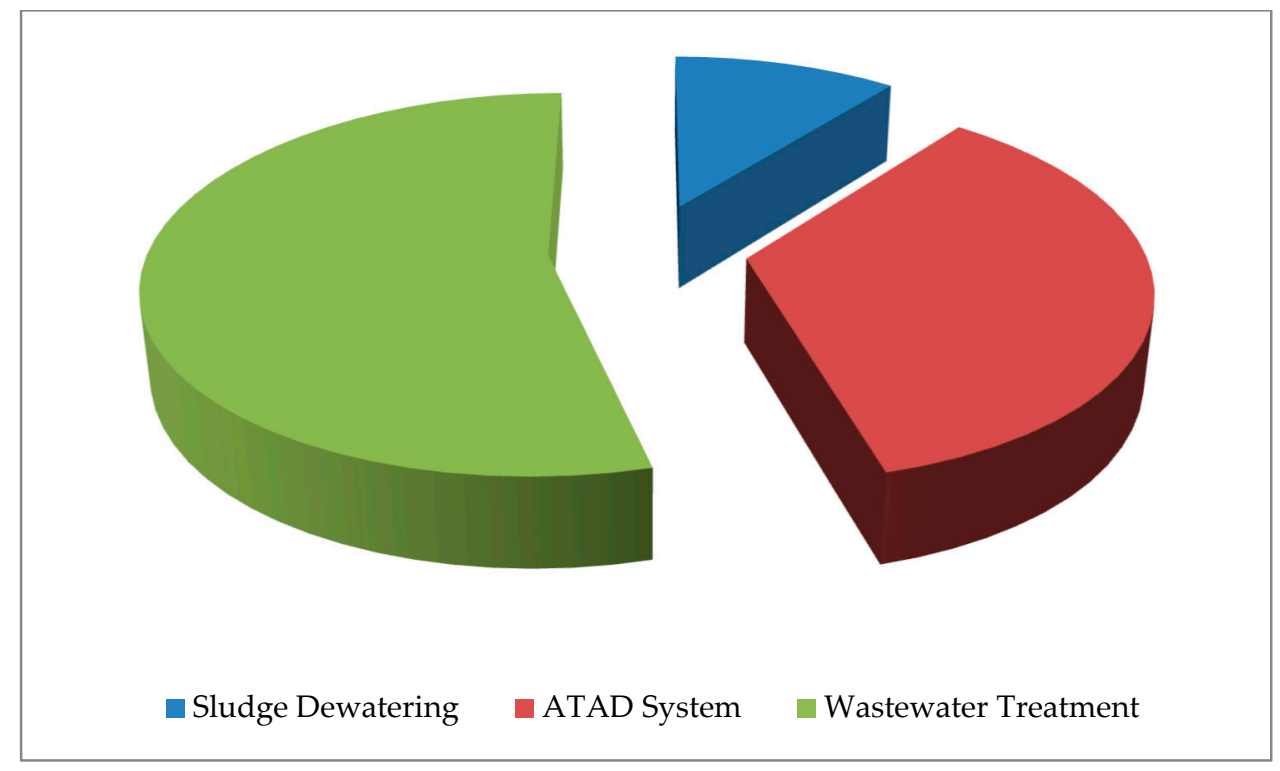

Figure 1. Share of technological processes in total annual electricity consumption.

The knowledge of the energy balance of a sewage treatment plant allows to assess the power consumption by individual processes by means of technical indicators giving the amount of electricity consumption in relation to $1 \mathrm{~m}^{3}$ of treated sewage sludge. In the examined ATAD installations the values of electricity consumption indicators were determined.

\section{Characteristics of Sewage Sludge}

Qualitative studies of the sludge were carried out in the existing facilities in the years 20032019.The determinations required for the annual, collective data tabulations of data for the generated municipal sewage sludge were analysed. These include reaction, content of dry matter and organic substances, total and ammonia nitrogen, total phosphorus, calcium, magnesium and heavy metals (cadmium, copper, nickel, lead, zinc, mercury and chromium) and information on the content of live parasitic eggs and Salmonella bacteria.

\section{Conclusions}

Studies carried out in existing ATAD installations have confirmed the effectiveness of this process in gaining of stabilized and hygienised sludge. The process allows to obtain sludge that do not putrify, and are free of pathogenic microorganisms, parasites and fungi. The sludge is sanitary and hygienic safe, while it contains fertilizers which, as a valuable commodity, can successfully be returned to the natural cycle.

Author Contributions: I.B., P.B. and I.A.T. conceived and designed the experiments; I.B., P.B. and I.A.T. analyzed the data; I.B. wrote the paper. All authors have read and agreed to the published version of the manuscript. 
Acknowledgments: The research was carried out as part of research work plan WZ/WBiIŚ/2/2019 at the Bialystok University of Technology and financed from a subsidy provided by the Minister of Science and Higher Education.

Conflicts of Interest: The authors declare no conflict of interest. The founding sponsors had no role in the design of the study; in the collection, analyses, or interpretation of data; in the writing of the manuscript, and in the decision to publish the results.

\section{References}

1. Layden, N.M.; Bartlett, J. Production of biosolids by ATAD from a highly variable municipal source. In Proceedings of the 10th European Biosolids and Biowastes Conference and Workshop, Wakefield, UK, 1316 November 2005.

2. Mavinic, D.S.; Mahendraker, V.; Sharma, A.; Kelly, H.G. Effect of microaerophilic conditions on autothermal thermophilic aerobic digestion process. J. Environ. Eng. 2001, 127, 311-316.

3. Shugen, L.; Nanwen, Z.; Ping, N.; Xudong, G. Semicontinuous Operation of One-Stage Autothermal Thermophilic Aerobic Digestion of Sewage Sludge: Effects of Retention Time. J. Environ. Eng. 2013, 139, 422-427.

4. Ugwuanyi, J.O.; Harvey, L.M.; McNeil, B. Diversity of thermophilic populations during thermophilic aerobic digestion of potato peel slurry. J. Appl. Microbiol. 2008, 104, 79-90.

5. Zupančič, G.D.; Roš, M. Aerobic and two-stage anaerobic-aerobic sludge digestion with pure oxygen and air aeration. Bioresour. Technol. 2008, 99, 100-109.

6. Sokolovs, A.; Grigans, L.; Dzelzkaleja, L.; Majore, G.; Bikulciene, L. Heat recovery technologies from aerobic bio-degradation: From theoretical finding to modeling results. Procedia Comput. Sci. 2015, 77, 141150.

(C) 2020 by the authors. Licensee MDPI, Basel, Switzerland. This article is an open access article distributed under the terms and conditions of the Creative Commons Attribution (CC BY) license (http://creativecommons.org/licenses/by/4.0/). 